\title{
KAREN HEWITT, A SCHOLAR WHO BRIDGES RUSSIAN AND BRITISH CULTURES*
}

\author{
Olga Sidorova \\ Ural Federal University, \\ Russia, Yekaterinburg
}

This article is devoted to Karen Hewitt, an Oxford lecturer and scholar in the field of English and Russian literature and comparative literary studies who became an MBE (Member of the Order of the British Empire) for services to building academic and cultural understanding between the UK and Russia in 2014. Different aspects of her activities - teaching in Oxford and several Russian universities, research, editing and publishing, organising academic contacts are aimed at bridging the two cultures and establishing academic collaboration between Russian and English scholars. Much attention is paid to Karen Hewitt's project 'Contemporary English Literature in Russian Universities', run by her with the financial support of the Oxford-Russia Fund. The project has united representatives of more than 100 universities from Russia and Belarus.

Keywords: Karen Hewitt; English literature; Russian literature; academic collaboration; bridging cultures.

Статья посвящена Карен Хьюитт, преподавателю Оксфордского университета, специалисту в области английской и русской литературы и сравнительного литературоведения, которая в 2014 г. была награждена орденом Британской империи за осуществление академических и культурных контактов между Великобританией и Россией. Деятельность Карен Хьюитт разнообразна - преподавание в Оксфорде и в нескольких университетах России, научная работа, организация совместных академических мероприятий, но ее основной целью является установление связей между двумя культурами и обеспечение контактов между учеными и преподавателями двух стран. Особое внимание уделяется проекту Карен Хьюитт «Современная английская литература в российских университетах», который осуществляется при финансовой поддержке фонда «Оксфорд - Россия» и объединяет преподавателей из более чем ста университетов России и Белоруссии.

Ключевые слова: Карен Хьюитт; английская литература; русская литература; научное сотрудничество; культурные контакты.

* Citation: Sidorova, O. (2017). Karen Hewitt, a Scholar who Bridges Russian and British Cultures. In Quaestio Rossica, Vol. 5, № 4, p. 927-937. DOI 10.15826/qr.2017.4.259.

Цитирование: Sidorova O. Karen Hewitt, a scholar who Bridges Russian and British Cultures // Quaestio Rossica. Vol. 5. 2017. № 4. P. 927-937. DOI 10.15826/qr.2017.4.259.

(C) Sidorova O., 2017

Quaestio Rossica • Vol. 5 • 2017 • № 4, p. 927-937 


\section{Karen Hewitt - in her own words (commenting the site information)}

The official Oxford University website states:

\section{Hewitt, Karen Rutherford}

Position: Lecturer

College: Oxford University Department of Continuing Education

Period / Subject: 1900 - to Present Day

Research interests: Russian Literature; English and Russian Literature - comparative studies; Contemporary British Fiction.

Teaching Areas: English and Russian [Hewitt Karen].

"The web site isn't quite accurate. Most of us (lecturers, or tutors of Department of Continuing Education) teach much more widely than the tutors teaching ordinary students. I teach many authors between the $16^{\text {th }}$ and $21^{\text {st }}$ centuries.

On the other hand, Research Interests is not quite accurate either. I teach more comparatively than most, but I haven't really written on these themes. I used to write for scholarly journals in Britain until I started coming regularly to Russia when it seemed to me that it made more sense to write for Russians since there are plenty of British critics to write for British readers" [Hewitt, 2016].

Many people who are acquainted with Karen Hewitt will immediately understand that the information given by the site lacks a few details, because so many things are not mentioned there. We know Karen Hewitt to be not only an Oxford lecturer and specialist in literature, but also an interesting scholar, an editor, a publisher, a brilliant organizer of British - Russian collaboration in the field of culture and education, an ardent traveler who has visited more Russian regions than any of us, a propagator of English culture in Russia and of Russian culture in Britain, an interesting interlocutor and a good friend. I would like to write this article about Karen Hewitt, whom I have been actively collaborating with for more than twenty years, and to mention briefly at least several of her interests and activities that are closely connected with Russia in general and Ural Federal University in particular.

Karen Hewitt has been teaching in Oxford since 1963. She is a tutor in Literature at Oxford University Department of Continuing Education. Her Oxford students are mainly grown-up people (there are people of all ages, including a considerable number of pensioners, among them) - adult education is a very characteristic British activity, and the Department of Continuing Education offers various types of classes for adult learners. Many of these classes are devoted to reading and discussion of literature; some of them are regularly conducted not in Oxford, but in many places, towns and villages, around the city. Karen Hewitt describes her teaching interests in the following way: "Since most literature was actually written by grownups for grown-ups, (and not as material for examination questions for students), the adults at these classes are often the best readers. They know what 
the writers mean - from their own experience and those of their families and their acquaintances. I have learnt enormously from discussions with my classes in Oxfordshire and the surrounding counties" [Hewitt, 1997, p. 14]. Several times, when I was in Oxford, Karen invited me to attend her classes where books of Russian writers were discussed. Thus, I attended a class devoted to Fathers and Sons by I. Turgenev, to Steppe by A. Chekhov and The White Guard by M. Bulgakov - the last one took place in 2014, when the Russian-Ukrainian crisis was in full swing. Every time, students seemed to be well-read, well-prepared, interested in discussing the texts and asked me several questions about them. The White Guard class was a part of a weekly class programme in Literature entitled Mikhail Bulgakov: Novels and Stories (10 meetings). Describing the course programme, Karen wrote: "The term will be devoted to detailed discussion of A Country Doctor's Notebook, The White Guard, and The Master and Margarita by Mikhail Bulgakov. We will read the books in this order. Issues to be discussed will include Bulgakov's narrative skills, his dramatic perception of scenes, his inventive moving from genre to genre, his exploration of the Civil War in Kiev in 1918, the recreation of the Pilate story, the culture of Soviet Moscow, and the recurring spiritual questions that he demands of himself. His writing is very readable and yet very complex so there is much to explore" [Weekly class programme]. Sometimes books by Russian writers are included by Karen Hewitt into a vast European literary context, for example, during the same term her course Many Kinds of Love - a Literary Study (20 meetings) was described thus: "A course on the literature of erotic love, sibling love, forbidden love, spiritual love, and the chemistry of love. The works will include Thomas Mann's Death in Venice, a novella of the artist grappling with dangerous enticements, Emily Bronte's disturbing and violent novel, Wuthering Heights, Turgenev's charming but very disconcerting novella, First Love..." [Weekly class programme], along with several other books. In 2016, her course Places and Obsessions: Some Literary Classics includes Steppe by A. Chekhov along with Robinson Crusoe by D. Defoe, The Return of the Native by T. Hardy, Germinal by E. Zola, and some other famous books of fiction.

Karen Hewitt teaches not only in Oxford - for the last twenty-five years she has been teaching in universities all over Russia, from Yakutsk and Vladivostok to Smolensk and Pyatigorsk, explaining Britain and British literature to Russian academics and students. Without any exaggeration, Karen Hewitt is an absolutely unique personality. She has been bridging Russian and British literature and, what is more, Russian and British people for almost three decades. Having started her career as a teacher of English in Oxford, Karen first came to Russia with a group of her mature students in 1984. She describes it in the following way: "I remember the class of grown-ups in the village of Shrivenham on the borders of Oxfordshire who were so impressed with Anna Karenina and The Brothers Karamazov that they insisted on organizing a group to visit Russia in those distant days of 1984. We came to Russia in order to find out more about your literature, in a visit that proved to be a revelation" [Hewitt, 1997, p. 14]. 
In 1985 she began corresponding with Dr Boris Proskurnin who invited Karen to visit Perm in 1989, when the city was opened to the foreign visitors, and much to the Moscow public's astonishment, Karen agreed to come not as a tourist, but as a university teacher and spent six weeks there. Many people can still remember life in Russian provincial cities of that time - empty shops, low salaries (if any), political changes, enthusiasm along with despair, and, as Karen herself recollects, she enjoyed freedom to do what she wanted, to meet different people. The University Rector Professor V. Malanin offered Karen Hewitt to help and to promote academic contacts between Oxford and Perm universities, and soon the two institutions signed a contract to establish academic links. Karen Hewitt has been teaching in Perm for more than twenty years now - she is an Honorary Professor of Perm State University and comes to Perm every year.

She began to meet the wider community of Russian scholars working on English literature. In 1990, Boris Proskurnin introduced her to Professor Nina Pavlovna Michalskaya, one of the leading Russian specialists in the field of English literature, who later became Karen's good friend.

Besides, she is often invited to come to different Russian universities thus, she has visited Ural State (now Federal) University eight times; her last visit took place in May 2016. During that visit, Karen conducted a number of master-classes with teachers in the Germanic Philology Department, as well as several tutorials with the Department's students. She also delivered several lectures for students specializing in the humanities.

Karen Hewitt's activities in establishing and developing British - Russian cultural and educational links are not confined to teaching. She has written, collected and edited several books for Russian readers in English. Her Understanding Britain was published in two editions (1994, 1996), translated into Russian and has long been a bestseller. In her introduction to the 1996 edition, the author writes: "This book is a personal account of Britain and of British life specially written for the Russian reader... Above all, Understanding Britain is an attempt to explain" [Hewitt, 1996, p. 7] to explain two nations and two cultures to each other. In 2009, a newer version - Understanding Britain Today - appeared. The first book was followed by Understanding English Literature (1997) and Understanding British Institutions (1998), a collection edited by Hewitt devoted to many sides of contemporary British life, where the leading British specialists in various fields contributed chapters. Later, she compiled and edited several other anthologies: Contemporary British Stories (1994), A New Book of Contemporary British Stories (2005) and An Anthology of Contemporary English Poetry (2003). All the aforementioned books have been extensively used both for research and teaching in a vast number of universities all over Russia, the Ural Federal University being one of them.

Over the last ten years, Karen Hewitt's activities in Russia have been connected with the Oxford-Russia Fund. She organizes annual seminars on contemporary English fiction (usually held in Perm, but sometimes in other Russian universities) for the Russian teachers of English and British literature - teachers from more than 75 Russian and Belarusian universities 
are involved - as well as academics, critics, and writers from Great Britain, the latter of whom come to Perm (or other universities) to conduct lectures, share their experience in teaching contemporary British fiction for Russian students and discuss different approaches and methods of teaching and research. More than 20 books of fiction were thus distributed among the universities (the total number of copies exceeds 60,000) - novels by Julian Barnes, Ian McEwan, Graham Swift, Nick Hornby, David Lodge, Hilary Mantel, Beryl Bainbridge and others. I have just named the leading British authors whose books were included into the list - but there are also a number of other writers whose books are less known to Russian readers. We, the teachers of the Germanic Philology Department of Ural Federal University, have been actively working with the books in question for many years, and all our students know them well. Karen Hewitt is also the Editor-in-Chief of Footpath, a British-Russian Journal of contemporary British literature that is financially supported by the Oxford-Russia Fund. It has become a discussion platform for teachers and researchers - the articles of both Russian and British contributors embrace a range of subjects, such as articles on recent British novels and plays, on poetry, on individual writers and genres, as well as articles on teaching, reviews, letters to the editor and students' essays.

In 2014, Karen Hewitt was awarded an MBE (Member of the Order of the British Empire) for services to building academic and cultural understanding between the UK and Russia. Asked to comment on the award, Mrs Hewitt said: 'I was thrilled to receive the MBE for work which would not have been possible without the support of many colleagues at the Department for Continuing Education and throughout the University. I first taught in a Russian university in 1989 and realised how difficult it was for intelligent and thoughtful Soviet university teachers to understood western societies and culture. They needed books and explanations and academic opportunities as their country was undergoing an agonising transformation. I was able to pioneer schemes which were supported by the Department for Continuing Education, by the University's agreement with Perm State University, and later by St Antony's College's Russian Centre. In recent years, thanks to the Oxford Russia Fund, I've been able to bring thousands of books, especially of contemporary literature, to teachers and students all over Russia. The experience has been fascinating and academically absorbing' [Hewitt, interview]

\section{Karen Hewitt - in her own words (commenting on the interview)}

"I did indeed say this, but remember that this interview was for Oxford University. Elsewhere I said (just as truthfully) that 'I was thrilled to receive the MBE for work which would not have been possible without the support of many colleagues in Russian universities" [Hewitt, 2016].

The following part of the article is Karen's letter to me written in October, 2015 - one of many letters, though unique, since usually she doesn't write about herself much. I asked her several questions concerning the origins of her interest in Russian literature, her teaching experience and Russian literature reception in England. Her answers to some of my questions are enclosed. 


\section{Karen Hewitt - in Her Own Words}

Question: When and why did you get interested in Russian literature? How did it happen?

K. H. "When I was eleven years old and in my new big school, I volunteered to help in the school library. This meant arranging, dusting and exploring the books in my special section, 'Junior Fiction', during the dinner hour when other unfortunate people had to go out into the wet playground. Snug in the large quiet room, I pulled out a fat volume called Great Short Stories of Detection, Mystery and Horror. There were a few black and white illustrations which caught my eye, one showing a horrible old woman glowering and holding up a playing card. Since I was enthusiastic about card games I read the story, 'The Queen of Spades' but I remember being puzzled because the game was not explained to the reader. How had the Countess used the rules to play a trick on Hermann. What exactly had she done? To this day most readers don't quite understand, but I have a tattered old pamphlet on 'The Rules of Faro, an Excellent Game' slipped in among my notes on Pushkin. I don't think I noticed at the time that the author was Russian, simply that he had failed to provide necessary information!

The public library in our small town did not normally allow children to graduate to grown-up fiction until they were fourteen. Presumably this was to keep us from sexual secrets, but since in those days there was immense censorship on any kind of sexual explicitness, I doubt if our minds would have been corrupted. In any case, I was not at all precocious in such matters, but I had heard that there was a Great Russian Writer called Tolstoy whose Great Novel was in the grown-up part. Could I, even if I was only thirteen, please use this section? The authorities graciously allowed me to approach the shelves. I found a fat novel by A. N. Tolstoy - the first book on the shelf which was called Peter the Great. My notions of Russia were vague. We hadn't done anything about Russia in history except for the essential fact that Russia was 'discovered' by brave English sailors who were wrecked in the White Sea, travelled to Moscow and were shocked by the Tsar's golden riches while the poor people starved in the gutters.

So I began reading Peter the Great and I do not think I ever finished it. But I read many pages, and I can still remember the shock, my disbelieving horror, my bewilderment at the incomprehensible cruelty of someone who was still described as 'great'. I struggled to bring my notions of history, the stories of chivalry, Elizabeth defying the Spanish Armada, the arguments over King and Parliament during the English Civil War (I was already interested in politics) into line with the dark, savage, unforgettable world of Peter the Great. There seemed to be no connection.

Shaken, I returned the book to the library and moved my hand along the shelf. The next volume was by L. N. Tolstoy and was called War and Peace. So I started reading that. But as I remember, it did not stir me in the same way as Peter the Great; besides, if you looked at the opening pages, half of it seemed to be in French! 
When I was fifteen, my grandfather gave me some money. While on holiday in Wales, I dragged my family to a little bookshop in a remote town among the mountains. Nothing seemed worth buying until I saw the Penguin [classic paperback] translation of The Brothers Karamazov. By this time I had heard of Dostoevsky, so I bought the book for reading on those endless rainy days characteristic of Welsh holidays. Even so, I was a little nervous. Would I understand this long novel? I was quickly reassured for this was a story about a man who had three sons, and even on page 1 it was clear that there would be a murder mystery. These fundamental facts kept me reading through pages and chapters where nothing made sense. Alyosha was boring, Ivan was incomprehensible, and the ladies were very peculiar indeed. But Mitya! I didn't exactly fall in love with Mitya, but I was swept along with him in extraordinary exhilaration. His passion for Grushenka, his agonies about whether he had behaved badly or not, his mad wild rush to Mokroye in the troika for an extravagant party and dramatic self-sacrifice, all this was entirely fresh and mind-expanding to someone used to the dutiful morality of English novels. At some level I knew that, judged by our world, Mitya was, if not exactly a bad man, then a dangerous, troubled, wicked man, but I had found a different kind of judgement and I revelled in it.

I have read The Brothers Karamazov perhaps six or seven times since then, and each time I reassess it my sense of where it is most powerful and where it is least convincing changes. I will never feel about Mitya as I did when I was fifteen, but I am still deeply grateful for the experience.

Those are my first memories of reading Russian literature. I was always reading, so Russian literature was taken on along with English and Scots and French and German and American literature; there was so much to learn of all these Great Writers that I do not remember putting Russian works into a special box until I was in my early twenties and beginning to teach adults. Then I had to be more systematic, more knowledgeable about contexts and about other works by these writers, more critical and careful in my responses. My teaching allowed me great freedom to choose my syllabuses for each class. With my students I could wander and explore, so long as I felt that I had solid information and understanding beneath my discussions with them. I quickly found that Tolstoy and Dostoevsky were wonderful for class discussion; and gradually I added Pushkin's prose, Lermontov, some Gogol stories, Turgenev, some Leskov and above all many, many Chekhov stories. This for me was (and is) the classic Russian course although I have to select from these writers in order to go into their works in proper depth. This term, for example, I have ten two-hour sessions on Father and Sons (which I love) and The Possessed or Devils (Бесbl) about which I have very mixed feelings. The first three classes will be devoted to Turgenev and the other seven classes to Dostoevsky. The great joy of teaching adults is that I can spend this time on novels which undoubtedly deserve that kind of attention. It means that I have to re-read such novels every time I come to teach them, and I have been teaching for fifty years, 
so I must have read Devils five times, and Fathers and Sons countless times. I read in English - sometimes using two or even three translations, and with a copy of the Russian beside me. But alas, my Russian is not good enough for coping with Dostoevsky, although I have read several Chekhov stories and great chunks of Turgenev in Russian, slowly but with much love.

Question: Do you read books of Russian authors in the original or in translation?

K. H. You lose an enormous amount in translation. As native English readers, we can discuss George Eliot or Thomas Hardy or Dickens in ways which are impossible when we are reading translations of Tolstoy or Turgenev. The words, the phraseology, the imagery, the oddities of syntax, the juxtaposition of epithets is a resource in one's own language which one is denied in reading translations, however good. Nonetheless something adequate emotionally and stylistically can be achieved in translating prose. I do not, however, believe that one can translate poetry except to give a basic outline of style and plot (for example in Evgeny Onegin). If you turn to the words, the sound, the rhythm, the phraseology - all those components of language which distinguish one poem from another - what is available in one language is so very different from what is available in another that the effect of a translation is utterly banal. Lots of writers, including poets, do not agree with me. And I accept, for example, that Seamus Heaney has made an impressive rendering of Beowulf, but he is a poet, re-writing an epic tale in a language not so very different from his own. Renderings of lyric poetry are, I think, inevitable failures. So I never teach poetry in translation.

Because I have come to spend much time in Russia and (I think) to know something of its inhabitants, culture and ways of seeing the world in some detail, I enjoy teaching Russian literature. I can offer this to students in a way that most of my colleagues cannot. Do I think that Russian prose fiction is in some way exceptional, unlike that of any other literature? Perhaps there is something distinctive - but I am uneasy about the term 'exceptional'. I know that 'Russian literature' does not work like 'English literature' or 'German literature' or 'French literature'. But all of these are unique cultural heritages which are also available, in diminished form, to the rest of the world. I do not want to suggest that there is a 'Russian literature' which somehow stands against the literatures of the rest of the world. Perhaps Russians will feel that; but as a good Englishwoman I happen to be well assured that the greatest literature in the world is English literature. Of course it is - for me - because it is using my language, the language with which I am intimate, in which I experience passion and anger and grief and comedy in life and in literature. So I cannot compare English and Russian, though you have to admit that our heritage goes back much further.

It was difficult for me to write this last paragraph to you because I had to check and emphasis the ironic-humour-which-is-also-stating-a-truth. I could not be sure (I cannot be sure) that you are hearing my tone. That's one of the difficulties about translation, incidentally. 
Question: What Russian writers and books are popular with the English readers?

$K . H$. If I am asked to define classic Russian prose I would say that the writers do not share a style or an emotional centre or a set of moral values. So what does connect Pushkin, Gogol, Lermontov, Turgenev, Dostoevsky, Tolstoy and Chekhov? (Or Goncharov, Leskov and Saltykov-Shchedrin?) What they seem to me to share is an intense sense that life matters, even when life is most boring or unendurable. Perhaps they are saying, 'You have no right not to care!' One does not put down a Russian classic novel or tale and ask oneself, 'Why did I bother to read that?' The other side of that coin is that readers can (rightly) get very exasperated by these great giants of fiction. If every second line of a Dostoevsky novel is a moment of extreme tension and potential revelation, we long for passages where we can relax, if only for a few pastoral moments. But Dostoevsky does not do pastoral; nor has he any sense of the material world or the world of daily chores, though he does enjoy food. Tolstoy on the other hand is immensely responsive to the quotidian realities and to the work of everyday life. His sin (and it is a $\sin$ ) is to moralise against his characters in a reductive and distorted manner. Anyone reading Anna Karenina must surely at times have wanted to throw the book at Lev Nikolaievich and denounce him for being untrue to his creations. He can make us very angry; we care about his untruths precisely because we care about his perceptive and often brilliant truths.

Because life matters so much to Russian writers, they can expose the raw pains of emotion, the contradictions and erratic absurdities of fraught conversations, and the vulnerability of almost anyone who tries to do anything. Often they can be very funny; Tolstoy has no sense of humour, but all the others are jubilantly conscious of the absurdities of life. However, unlike many English writers, they make no attempt to establish a sustained ironic mode through which to view the world. They are more open, more unsteady, more liable to step down into the pit themselves. Social cohesion seems never to occur to them: they can explore the intimate and the apocalyptic - but not the civic concern for other people. Chekhov would like to do that, but he is terribly aware of human failure

Question: Could you tell us about your students who take different courses in Russian literature? What are they motivated by? Could you describe their reactions/preferences/impressions?

K. H. I am a professional reader and teacher of literature. It is very difficult for me to gauge how many people in Britain read Russian literature. British publishers care about the quality of translations of the classics more, I think, than Russians. How many good, serious and competing translations of George Eliot, Charles Dickens, Thomas Hardy, Jane Austen and other classic writers can one find available in Russian bookshops? In my class my students are reading from six different translations of Fathers and Sons. Some of these are now out of print, but all of them have been 
recently available. Academic journals are filled with scholarly discussions comparing one translation with another and drawing the reader's attention to the strengths and limitations of any individual approach to translation. (We are far less preoccupied with the theory of translation than you are.) The average reader is not going to notice these debates, but he will certainly notice the different translations published by our 'classic' publishers such as Penguin and Oxford University Press. Among educated readers who expect to spend their adult lives reading (I am not talking about professionals like myself but amateur adult readers) many feel that until they have read 'the Russians' they cannot count themselves as properly educated. But this is a tiny minority. Some of them turn up at my classes. Currently I have two students in my evening class studying Turgenev and Dostoevsky who are there because they feel strongly that they 'ought' to read Dostoevsky. One of them is passionate about him and travels 80 kilometres from his home to Oxford to take part in the class. The second one fears that Devils will be too hard for him unless he gets help. The rest are there because they want to study serious books. This seems to me such an obvious desire that I do not ask myself these questions about motivation. We read and discuss because we care about what we read, just as we look at pictures in art galleries and listen to experts analysing them if we care about art, or go to concerts so that we can listen to music and ruminate about it later" [Hewitt, 2015].

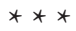

In October, 2016, Karen wrote in her letter to me:

As for me, I really want to bridge the cultures, and at the moment that means 'politically' as well as 'in literature'. I see my job as explaining. So far I have given a lecture in Russia on "Brexit" - what happened, why, and future consequences' four times in Russia and once to an international summer school here. Also I am trying to give Russian academics in the humanities, especially literature, opportunities to read and work either in Britain or with decent English books. I don't think it is exactly joint academic work because Russian and English traditions are very different, but that's OK. We learn from different cultures [Hewitt, 2016].

\section{Список литературы}

Hewitt Karen // University of Oxford. Faculty of English Language \& Literature [official website]. URL: http://www.english.ox.ac.uk/about-the-faculty/faculty-members/ research-centre-and-college-staff.html (mode of access: 25.10.2016).

Hewitt $K$. Understanding Britain. $2^{\text {nd }}$ ed. Oxford ; Nizhny Novgorod : Perspective Publ., 1996. $265 \mathrm{p}$.

Hewitt K. Understanding English Literature. Oxford ; Nizhny Novgorod : Perspective Publ., 1997. 297 p.

Hewitt K. A letter to O. Sidorova. Oct. 22, 2015.

Hewitt K. A letter to O. Sidorova. Oct.16, 2016.

Interview with Karen Hewitt// University of Oxford [official website]. URL: https:// www. ox.ac.uk/news/2014-01-02-news-year-honours-2014 (mode of access: 25.10.2016). 
Weekly Class Programme in Literature, 2014 // University of Oxford. Department for Continuing Education [official website]. URL: www.conted.ox.ac.uk (mode of access: 25.10.2016).

\section{References}

Hewitt, K. (1996). Understanding Britain Today, $2^{\text {nd }}$ ed. Oxford, Nizhny Novgorod, Perspective Publ. 265 p.

Hewitt, K. (1997). Understanding English Literature. Oxford, Nizhny Novgorod, Perspective Publ. 297 p.

Hewitt, K. (2015). A letter to O. Sidorova. Oct. 22, 2015.

Hewitt, K. (2016). A letter to O. Sidorova. Oct.16, 2016.

Interview with Karen Hewitt (2016) // University of Oxford [official website]. URL: https://www.ox.ac.uk/news/2014-01-02-news-year-honours-2014 (mode of access: 25.10.2016).

Hewitt Karen (N. d.) // University of Oxford. Faculty of English Language \& Literature [official website]. URL: http://www.english.ox.ac.uk/people/karen-hewitt (mode of access: 25.10.2016).

Weekly Class Programme in Literature (2014) // University of Oxford. Department for Continuing Education [official website]. URL: http://www.conted.ox.ac.uk (mode of access: 25.10.2016).

The article was submitted on 11.09.2017 